Comparative Industrial Systems 


\section{Comparative Industrial Systems}

Industry under Capitalism, Central Planning and Self-Management

Trevor Buck

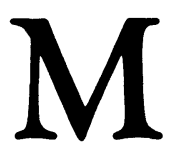


All rights reserved. No part of this publication may be reproduced or transmitted, in any form or by any means, without permission.

First published 1982 by

THE MACMILLAN PRESS LTD

London and Basingstoke

Companies and representatives throughout the world

ISBN 978-0-333-31114-1 ISBN 978-1-349-16701-2 (eBook)

DOI $10.1007 / 978-1-349-16701-2$

The paperback edition of this book is sold subject to the condition that it shall not, by way of trade or otherwise, be lent, resold, hired out, or otherwise circulated without the publisher's prior consent in any form of binding or cover other than that in which it is published and without a similar condition including this condition being imposed upon the subsequent purchaser. 
For Bill 


\section{Contents}

Preface ix

List of Tables xii

1 The Theoretical Yardsticks 1

1.1 Components of Economic Efficiency 2

1.2 Perfect Capitalism 7

1.3 Perfect Central Planning 13

1.4 Perfect Self-management $\quad 15$

1.5 The Role of Perfect Models 16

2 Theories of the Capitalist Firm 19

2.1 The Neoclassical Paradigm 20

2.2 Towards Realism within the Paradigm 22

2.3 Behavioural Theories $\quad 36$

2.4 Capitalist Dynamics 38

2.5 Empirical Evidence and Conclusions 42

3 Theories of the Centrally Planned Enterprise 49

3.1 The Planned Enterprise - Statics 50

3.2 The Planned Enterprise - Comparative Statics 55

3.3 Models for 'Ratchet' Solutions 60

3.4 Empirical Postscript-China and the Soviet Union $\quad 65$

4 Theories of Self-Management 77

4.1 The Labour-managed Firm (LMF) 79

4.2 The Worker-managed Firm (WMF) 98

4.3 Risk-bearing and Self-management 105

4.4 Empirical Postscript: Yugoslavia, etc. 113

5 Actual System Performance 124

5.1 Micro-static Efficiency 128

5.2 Macro-static Efficiency 132 
viii

Contents

5.3 Dynamic Efficiency 146

5.4 Conclusions 154

Bibliography 159

Author Index $\quad 171$

Subject Index $\quad 175$ 


\section{Preface}

At the risk of alienating any students or tutors who may use this book, I have to admit that courses in comparative economic systems usually enjoy low status. Such courses, and the texts on which they are based, are often too broad and encourage shallow work. More importantly, they may lack any organised approach to the subject and soon get bogged down in institutional detail, of ten with the names of countries as chapter (or lecture) titles.

For these reasons, this text focuses on the industrial enterprise under three abstract forms of enterprise control: capitalism, central planning and self-management. It concentrates on the motivational features of these systems (see Table $1.1 \mathrm{p.}$ ), and uses the deductive theory of the firm as an organising device, providing the basis for the subsequent description and analysis of actual economies where these enterprise forms predominate.

Of course, students are often intolerant of deductive theory and claim with some justification that it is based on unrealistic assumptions and is devoid of predictive ability. Indeed the clatter of pens that often follows the introduction, 'et us assume that ...' discourages any development of this approach. The reasons for doing so here must therefore be spelled out.

As Joan Robinson has remarked, the fundamental problem with a map of scale one-to-one is that you must travel on it! This text adopts her position that simplifying assumptions are necessary both for navigation and economic analysis, and that students should consider not the detailed accuracy (or otherwise) of any assumptions, but whether a theory built upon them captures the essence of an economic mechanism, albeit one of many. At the very minimum, deductive theories provide an organised stock of explanations for the observed aggregate performance of actual, as opposed to theoretical, industrial systems. It is conceded, however, that these theories 
cannot perform a full scientific function in the sense that laboratory (or any other) tests are infeasible.

There are important limits to this approach. The analysis is restricted to what Marxists call 'commodity production', and it is clear that the theory of the firm, and the implied assumption of self-interested behaviour, effectively blinkers any analysis of industrial systems which may have been adopted with a wider perspective in view, encompassing, for example, the interdependence of individual decisions and the need for class soldarity. In this sense, the conclusions of the text are in the premises. Nevertheless, the approach used here provides a basis for contrast, subsequent modification and at least suggests potential flaws in systems (capitalist, centrally planned or self-managed) that may be experienced whenever self-interested behaviour arises or recurs. The approach is therefore basically neoclassical, but a close reading of Chapter 2 shows that it does not produce the unquestioning support for the capitalist system that Marxists expect.

It is equally clear that the form of enterprise control is not the only (and perhaps not even the most important) determinant of aggregate industrial performance, which will be heavily influenced by resource endowments together with geographical, political, cultural, historical and other variations. (Capitalist Japan and the USA currently provide a massive contrast in economic performance.) Again it has to be recognised that the blinkers are on, but it is suggested that it may be appropriate to investigate one (in this case economic) mechanism at a time, particularly for students new to the subject. Wiles $(1977$, p.4) insists, however, that 'The comparison of economic institutions is political economy - by definition. Comparisons that leave out non-economic types of information and reasoning are frauds.'

This may be true, but then Wiles ends up with an excellent book more than 600 pages long, which is probably unsuitable for all except the most widely read undergraduates. Those who disagree fundamentally with the approach adopted here may still benefit if it defines their positions more precisely.

Finally, a statement of values, so that readers can adjust their interpretation of what follows. The author favours experiments with rules to promote self-management as a 
solution to some of the most serious defects of capitalism and central planning. Such experiments should be conducted, however, with a consciousness of self-management's potential defects if accusations of naivety are to be avoided.

The analysis is aimed at the typical second- or third-year economics undergraduate with average mathematical ability. None of the mathematics goes beyond fairly simple differentiation and geometry, and in any case is accompanied by a parallel, verbal commentary. An extensive bibliography is provided for more advanced students.

January 1981

T.B. 


\section{List of Tables}

1.1 Components of Economic Efficiency 2

1.2 Classification of Economic Systems 8

5.1 Per Capita Income from All Sources after Income Taxes 129

5.2 Real National Income per Factor Input, $1960 \quad 138$

5.3 Average Annual Rates of Change in Retail Price Index, 1955-75

5.4 Official and Estimated Changes in Consumer Prices, 1958-73

5.5 Official and Estimated Changes in Consumer Prices, 1960-70

5.6 Growth of Real GNP and Inputs

5.7 US National Income per Person Employed in Non-residential Business

5.8 Rates of Growth of Real GNP and Inputs

5.9 Annual Growth Rates in Industry (Mining, Construction and Crafts), Yugoslavia 